\title{
Rules and Policies Related with Good Governance When Corona Virus 2019 (COVID19) Pandemic
}

\author{
Solechan \\ Faculty of Law, Diponegoro University, Semarang, \\ Jalan Prof. Soedarto, SH Tembalang, Semarang, Jawa Tengah 50275 \\ Email: han@live.undip.ac.id
}

\begin{abstract}
The policy made by the government in relation to COVID 19, became a quite heated discussion among the community. In fact, many observers are questioning the policy. At present, the government is faced with two choices, namely maintaining the lives of citizens or maintaining the economy. Policies taken by the government must be based on the principle of good governance. The principle of good governance is an important principle in making policy. One of the principles in good governance is the principle of community participation. Through this research, we will see how community participation is related to policies made by the government, moreover, public awareness is still lacking related to government policies to deal with this pandemic.
\end{abstract}

Keywords: Government, principle, community participation

\begin{abstract}
Abstrak
Kebijakan yang dibuat oleh pemerintah terkait dengan COVID 19, menjadi pembahasan yang cukup hangat dikalangan masyarakat. Bahkan, para pengamat banyak yang mempersoalkan kebijakan tersebut. Saat ini, pemerintah dihadapkan dengan dua pilihan, yaitu mempertahankan nyawa warga negara atau mempertahankan perekonomian. Kebijakan yang diambil oleh pemerintah, harus didasari oleh prinsip good governance. Prinsip good governance ini menjadi prinsip yang penting dalam mengambil kebijakan. Salah satu prinsip yang ada di good governance adalah prinsip partisipasi masyarakat. Melalui penelitian ini, kita akan melihat bagaimana partisipasi masyarakat terkait kebijakan yang dibuat oleh pemerintah, terlebih lagi, kesadaran masyarakat yang masih kurang terkait dengan kebijakan pemerintah untuk menangani pandemi ini.
\end{abstract}

Keywords: Pemerintah, Prinsip, Partisipasi Masyarakat

\section{A. Introduction}

At present, the whole world is faced with a COVID19 pandemic. The origin of this virus originated from Wuhan City in China. After the spread of the virus, the 
Chinese government decided to close all access in and out of China, especially Wuhan City. Then this virus spread throughout the world. The spread of this virus makes many countries take different policies to prevent the spread of this virus. Most countries in the world take a policy to close all access in and out of their country.

However, it is different from Indonesia which implements a large-scale social restriction policy or PSBB. This social restriction still allows the community to carry out activities but must comply with existing health protocols such as physical distancing, gathering no more than 5 people, wearing masks when on the move. When using a private vehicle, the number of passengers is limited. This policy was taken because the government still wants the economy to continue, and the needs of the community are still available in the market. But in reality, there are still many people who move outside, and do not pay attention to existing health protocols. There is still a lot of mass accumulation in several regions in Indonesia.

For example, what just happened at Sarinah and Soekarno Hatta Airport. Therefore, this government policy becomes a problem. Is this policy following the principles of good governance? Or is there still a lack of public awareness of this pandemic? We have to know that, the principle of good governance include the people participatory. These two questions became important topics during this pandemic. From the government side, the government has tried to ensure that community activities can take place during this pandemic. The government make sure that, all of activities including industrial activities still can continue but completed with some requirements.

The goverment also made a prohibition to stop some industrial activities except the daily needs industrial. That's the reason why there are many industrial activities which stop and many people lost their job. This become a big problem when government can't make a welfare for their cityzen. In social activities prespective, many people do not obey the rules that have been made by the 
government. As I saw for myself about social distancing, many people create crowds in the afternoon before breaking the fast.

This situation is like that there is no suggestion from the government to keep a distance. Besides, there are still people who do not use masks when traveling. Even though the government has recommended wearing masks when traveling. The government claims that this social restriction policy is successful in general. However, some provinces do not implement social restrictions but are successful, these provinces are the provinces of Bali. This means that this social restriction policy is effective in reducing the number of people exposed to this virus. It means social restriction is one of the solutions to press the people who spread this virus.

On the other side, social restriction makes a lot of people lost their job. To solve this problem, the government gives social assistance for the people who have an impact causes this virus. However, in providing social assistance there is a problem, namely the overlapping of data between the central government and regional governments. This happened in DKI Jakarta Province. The recipient of social assistance from the president was also a recipient of assistance from the Regional Government of DKI Jakarta. This means, there is a mismatch of data between the central government and regional governments. We will associate all of these problems with the principles of good governance as a reference in Indonesia.

\section{B. Discussion}

Community demands, to the government concerning government administration are increasingly intense. This is driven by increasing public knowledge about government. Along with the times and the many platforms, people can access all information, so they can express their aspirations related to governance. The principle of good governance, can we see whether the government has organized governance following UNDP. ${ }^{1}$

${ }^{1}$ Https://En.Wikipedia.Org/Wiki/Good_Governance 
In international development, good governance is a way of measuring how public institutions conduct public affairs and manage public resources in a preferred way. Governance is "the process of decision-making and the process by which decisions are implemented (or not implemented)". Governance in this context can apply to corporate, international, national, or local governance as well as the interactions between other sectors of society. According to the organizing principle State issued in article 2 of the Act No.28 of 1999, concerning Free clean host country from corruption, collusion, and nepotism, then there are some general principles of organization Country, which contains:

1. Principle of Legal Certainty:

Principle within Country the law which prioritizes foundation statutory regulations, propriety and justice in each state policy.

2. Orderly Principle:

The principle that becomes Basic rules, harmony, and balance organizer in control Country.

3. Principle of Public Interest:

Principle which puts welfare first general in a way who is aspirational, accommodating, and selective

4. The principle of openness

The principle of being open yourself up to people's right to receive information true, honest, and not discriminatory about State administration with keep watching protection of rights personal truth, class, and secret Country

5. Principle of Proportionality:

The principle of being prioritizing balance between rights and participation country organizer

6. The principle of professionalism:

The principle of being prioritizing expertise based on a code of ethics and statutory provisions applicable

7. Principle of Accountability: 
The Principle determines that each activity and the final results of the activities state administration must be can be accounted for to the community or the people as a holder State's highest sovereignty under the provisions applicable laws. ${ }^{2}$

Based on the explanation above, during this pandemic the focus was on the effectiveness and participation of the community. Community participation also depends on the extinguishing of human resources themselves. Human capital or human capital can be interpreted as the economic value of human resources related to abilities, knowledge, ideas, innovation, power and commitment (Schermerhon, 2005). Human resources are potential abilities possessed by humans consisting of abilities think, communicate, act and be moral to carry out an activity both technical in nature and managerial (Ardana et al, 2012: 5). Furthermore, The abilities possessed by humans can be used to achieve personal and organizational goals where the person works or is a part of the organization. ${ }^{3}$ Why these two things, because these two things are closely related to the policies that have been issued by the government during this pandemic.

We can see that, the rules set by the government have succeeded. The government claims, with the PSBB policy, can reduce the number of people exposed to the virus. Several provinces were also successful by this PSBB. In conclusion, the government claims this policy is the best, where the wheels of the economy in some sectors continue to run, without having to close all regions in Indonesia. This government policy is not accompanied by public participation. When the virus first appeared in Indonesia, people wanted a lockdown policy. Lockdowns of which can be associated with regional quarantine.

Regional quarantine is a population restriction in an area including the entrance area and its contents that are suspected of being infected with the disease and/or contaminated in such a way as to prevent the possibility of spreading the

\footnotetext{
${ }^{2}$ Kebijakan Pemerintah Dan Pertanggungjawabannya Dalam Rangka Good Governance Oleh: Alent R.Tumengko

${ }^{3}$ Sumber Daya Manusia, Good Corporate Governance, Dan Kinerja Perusahaan I G A M Asri Dwija Putri
} 
disease or contamination. among community members in the region ${ }^{4}$. During quarantine in the area, the basic living needs of people and animal feed in quarantine areas are the responsibility of the central government. ${ }^{5}$ Then, Article 8 of Law $6 / 2018$ stipulates that everyone also has the right to obtain basic health services according to medical needs, food needs, and other daily necessities of life during the quarantine. What is meant by "other daily necessities of life"? include the need for clothing and toiletries, washing, and urinating. ${ }^{6}$

Besides, everyone has the right to receive the same treatment in administering health quarantine. ${ }^{7}$ After that, the government issued this PSBB policy. Large-scale social restrictions are restrictions on certain activities of residents in an area suspected of being infected with a disease and/or contaminated in such a way as to prevent the possibility of spreading the disease or contamination. ${ }^{8}$ Large-scale social restrictions aim to prevent the wide spread of public health emergencies that are occurring between people in a certain area.

Experts consider that the government is incapable of treating the lockdown policy. The government does not have enough budget to fully fund the basic needs of its people. The President said in his interview with Najwa Shihab, for Jakarta alone in one day requires 550 billion. The initial implementation of the PSBB was still fairly good. Many people who obey the government's recommendations to worship, work, learn from home.

Although there were no strict sanctions, the initial implementation of the PSBB was quite good. The road at the beginning of the implementation of the PSBB was very quiet. There are only a few people on the streets. All was well and the number of victims exposed to the coronavirus continued to increase, as the number of rapid tests and swab tests increased. When the PSBB came into force, the government issued many regulations. Like closing all modes of transportation,

\footnotetext{
${ }^{4}$ Https://Www.Hukumonline.Com/Klinik/Detail/Ulasan/Lt5e74a69e9bf8d/Hak-Rakyat-Jika-

Terjadi-I-Lockdown-I-/

${ }^{5}$ Pasal 55 Ayat (1) UU 6/2018

${ }^{6}$ Penjelasan Pasal 8 UU 6/2018

${ }^{7}$ Pasal 7 UU 6/2018

${ }^{8}$ Pasal 1 Angka 11 UU 6/2018
} 
reducing Transjakarta bus ride schedules, and limiting passengers in private vehicles.

To 3close out all modes of transportation, the government is hesitant. The government seems inconsistent whether it wants to open or close the mode of transportation. In addition to inconsistent policies made by the government, there is also no strict law enforcement. The regulator only provides sanctions in the form of fines, as has been done by DKI Jakarta. If there are no strict sanctions, the community will feel that breaking the rules will not affect them.

This is happening amid the current PSBB. The PSBB policy seems lax, and many people are already on the road. All modes of transportation have also been opened, such as planes, ships. However, the government added provisions to include official letters and COVID-free letters19. Regarding this COVID19 free letter, several persons sell this free letter at 70,000 rupiahs. This is very alarming, where the public should be aware of the importance of safety, instead, it acts by endangering themselves and others.

The PSBB concessions have started to appear from the beginning, but at that time it was not too highlighted because of the small number of violators. Lately, many people have violated the PSBB rules. In addition to the opening of the mode of transportation, many people have left the house for things that are not important. As has just happened in Sarinah, many people gather to capture the last moment of a fast-food restaurant. It affected the restaurant and was fined 10 million rupiahs. Fortunately, the restaurant is quite cooperative, so they are willing to pay the fine.

Besides what happened in Sarinah, the buildup of people also occurred at Soekarno Hatta Airport in Tangerang. The buildup occurred after the government decided to open a mode of transportation. The buildup was caused by the queue of checking the departure documents of passengers who wanted to travel to several areas. The queue buildup also does not pay attention to health protocols and social distancing. This is very worrying, where the community should take care of themselves, instead, they are still selfish without thinking about how the fate of medical personnel who have struggled during this pandemic. 
Recently, many people visited the mall. They use this Eid al-Fitr moment to buy clothes. In a viral video recording on social media, we can see how many people enter the mall while running. But in the recording, we can see that there are still many shops that are closed. This also happened in the Tanah Abang market, for the same reason they visited the market to buy Eid. There are many more incidents like this, related to the lack of public awareness in situations like this. Then, the Governor of DKI Jakarta, Anies Baswedan decided to extend the PSBB period. PSBB plus 2 weeks. He hoped that this would be the last phase of the PSBB so that we could start a new phase in DKI Jakarta.

Regional autonomy is part of internal government policies that realize a system of government that is good (good governance). Autonomy has selfgovernment or owned by their interests. Autonomy regions are rights, authority, and Regional Obligations to regulate and Handling the household itself, accordingly with statutory regulations applicable. Currently the government system Indonesia has given freedom For the area in his area ${ }^{9}$. Regional autonomy exists in Law No.32 of 2004 About Regional Government. The legal basis implements autonomy regions are Article 18 of the 1945 Constitution reads as follows:

1. Unitary State of the Republic of Indonesia divided into provinces and regions he area of the province was divided into districts and cities, which are every-province, regencies, and cities owned the regional government, which is regulated by law.

2. Provincial, regional government District and city own settings according to the principle of autonomy and duty co-administration.

3. Provincial, regional government districts, and cities have Regional Representatives Council which its members are chosen through the general election.

4. Governors, Regents, and Mayors respectively as heads of government provincial, district, and city areas democratically elected.

\footnotetext{
${ }^{9}$ Telly Sumbu, Kamus Umum Politik Dan Hukum, Jala Permata Askara, Jakarta 2010, Hal 569 ( Diambil Dari Jurnal KEBIJAKAN PEMERINTAH DAN PERTANGGUNGJAWABANNYA DALAM RANGKA GOOD GOVERNANCE1 Oleh: Alent R.Tumengko
} 
5. The regional government runs the broadest possible autonomy, except the business-government which by law is determined as a matter of central government.

6. The regional government has the right to establish regional regulations and other regulations for carrying out autonomy and duty coadministration.

7. Composition and procedure for implementation local government is regulated in the constitution. According to Article 21 of the Law Number 32 Year 2004 regarding Regulation, the area explains the rights and Regional obligations namely in holding regional autonomy between others:

a. organize and take care of themselves government affairs;

b. elect regional leaders;

c. manage regional apparatus;

d. managing regional wealth;

e. collect local taxes and regional user fees;

f. get a revenue share from natural resource management and source other power that is on the area;

g. get resources other legal income; and

h. get other rights which are regulated in the Regulations legislation

Regional autonomy becomes very important during a pandemic like this because, in a situation like this, the region must be given the freedom to determine policies. At the beginning of yesterday, the president had stated that all regions must follow the rules of the central government (one command). This should not have happened, because Indonesia is a vast country and has different demographics and population. The infrastructure of each region is different. We can see, how the imbalances that occur between western Indonesia and eastern Indonesia. Like Papua, for example, health facilities there are very lacking. The number of hospitals can also be said to be less. From there, why regions should be given the freedom to determine their policies. If regions are not given full power to determine their regional policies, there will be unclear policies between the central government and 
regional governments. For the holding of congregational prayers in mosques, for example, in some areas it is permissible, but the central government bans congregational prayers in mosques.

This policy made by the government is not accompanied by a consistent level of government.

The government has made many policies and regulations, but the fact is, there are still many victims who are exposed to this virus increasing every meeting. Update the last number of people exposed to 900 and this is the highest in recent months. This proves that, the policies made by the government have not been effective, although the government claims to have succeeded in suppressing the number of people exposed to this virus. Indeed, to achieve an effective policy, it also needs support from the community, but the uncertainty of this policy that makes people angry and angry, and maybe this is also the background why many people do not comply with this. From this, we can see how low the quality of human resources in Indonesia. Community participation also depends on the extinguishing of human resources themselves. Human capital or human resources can be interpreted as the economic value of human resources related to abilities, knowledge, ideas, innovation, power and commitment (Schermerhon, 2005).

Human resources are potential abilities possessed by humans consisting of abilities think, communicate, act and be moral to carry out an activity both technical in nature and managerial (Ardana et al, 2012: 5). Furthermore, The abilities possessed by humans can be used to achieve personal and organizational goals where the person works or is a part of the organization. ${ }^{10}$ It has been explained above, that community participation is very important during a pandemic like this. From some of the problems mentioned above, most problems arise from us as citizens who do not comply with government recommendations. Indeed, the government also made mistakes, such as uncertainty of rules or fickle plans, and the absence of strict law enforcement for PSBB violators, but there is nothing wrong

\footnotetext{
${ }^{10}$ Sumber Daya Manusia, Good Corporate Governance, Dan Kinerja Perusahaan I G A M Asri Dwija Putri
} 
if we follow the government's correct recommendations. The latest update now, the government already looks like loosening the PSBB.

This proves, that the facts on the ground with the president's statement are far different. In the cikampek toll road for example, there are already 300,000 cars going out through the cikampek toll road. Besides, the buildup of passengers continues. Society as the front guard must work together and work together so that we can live a normal life again. Medical personnel has made every effort so that the number of patients exposed can be treated.

Finally, Related to the development of the virus, the government made a policy to keep the economic running with social distancing. This is interpreted transmission from COVID-19 is a real trickle splash of small mucus from the walls of the respiratory tract of a sick person out when coughing and sneezing. Therefore, the government agreed let the coughing and the cause of influenza disease to use a mask, approved for approval droplets from claimed. other than that In the distance between people, so that the opportunity for the disease can be lower. The implication is that meetings with large numbers and the buildup must be avoided. Therefore it is very important to be recognized together from all components of society for not carrying out activities that mobilize many people in one place which is not too broad and causes a crowd. This is considered as wrong a very effective aid to reduce the spread of the virus. Therefore, the social distance must be implemented, both in daily life, in the environment any work in the domestic environment apart from continuing to make revisions Through efforts to clean and healthy lifestyle by always washing hands use soap with running water.

\section{Conclusion}

The principle of Good governance is a way of measuring how public institutions conduct public affairs and manage public resources in a preferred way. Governance is "the process of decision-making and the process by which decisions are implemented (or not implemented)". Governance in this context can apply to corporate, international, national, or local governance as well as the interactions between other sectors of society. Based on the explanation above, 
during this pandemic the focus was on the effectiveness and participation of the community. Community participation also depends on the extinguishing of human resources themselves. Human capital or human capital can be interpreted as the economic value of human resources related to abilities, knowledge, ideas, innovation, power and commitment (Schermerhon, 2005). Human resources are potential abilities possessed by humans consisting of abilities think, communicate, act and be moral to carry out an activity both technical in nature and managerial (Ardana et al, 2012: 5).

Regional autonomy is part of internal government policies that realize a system of government that is good (good governance). Autonomy has selfgovernment or owned by their interests. Autonomy regions are rights, authority, and Regional Obligations to regulate and Handling the household itself, accordingly with statutory regulations applicable. Currently the government system Indonesia has given freedom For the area in his area ${ }^{11}$. Regional autonomy exists in Law No.32 of 2004 about Regional Government.

These three things become very important now. The government is required to make effective and successful policies to increase community participation to comply with these policies, which in the end, there are still many people who obey them. Government assertiveness is still lacking for now. Law enforcement for policy violators is not strict. We take the example of several events in Jakarta.

The closure of fast food restaurants in Sarinah, passenger buildup at the Soekarno Hatta Airport, and the bustling of several markets. In fact, in goverment pited from carrying out activities travel outside and/or enter DKI Jakarta Province]"p' during the non-natural disaster determination period, Corona spread Virus Diseas0000e 2019 (COVID-19) as a national disaster ${ }^{12}$.

Besides, the central government in the early days of exposure to the coronavirus in Indonesia, has not given full freedom to the regions to determine their policies. We know that Indonesia is a vast country, and has a different

\footnotetext{
${ }^{11}$ Telly Sumbu, Kamus Umum Politik Dan Hukum, Jala Permata Askara, Jakarta 2010, Hal 569

12 Peraturan Gubernur Daerah Khusus Ibukota Jakarta Nomor 47 Tahun 2020 Tentang Pembatasan Kegiatan Berpergian Keluar Dan/Atau Masuk Provinsi Daerah Khusus Ibukota Jakarta Dalam Upaya Pencegahan Penyebaran Corona Virus Disease 2019 (Covid-19)
} 
demographic. Although in the end, the central government gives local government freedom to determine its policies. In addition to the different demographics, health facilities in each region are also different. This is a challenge that must be opposed by our nation, inequality in several fields is still many and has not been resolved until now.

With so many violations committed by the people related to this PSBB, then we can conclude that human resources in our country are still low. The community is still concerned with his ego to leave the house, go to the market, to the mall, and so on. They do not realize that by staying at home, it has helped the work of medical personnel. We can leave the house if it is an emergency or we have to leave the house. Society is at the forefront in this pandemic, not medical personnel. It is our awareness that will help the country through this difficult time. Washing hands, wearing masks, social distancing, and sports are very easy for us to do.

\section{References}

I G A M Asri Dwija Putri,Sumber Daya Manusia, Good Corporate Governance, Dan Kinerja Perusahaan

Journal UIN Jakarta, Kebijakan Pemberlakuan Lockdown Sebagai Antisipasi PenangananCOVID19, http://journal.uinjkt.ac.id/index.php/salam/article/view/15083/pdf,

Kompas, Pengertian Otonomi Daerah dan Dasar Hukumnya, https://www.kompas.com/skola/read/2019/12/16/110000069/pengert ian-otonomi-daerah-dan-dasar-hukumnya?page=all, akses pada 22 mei 2020

Media Indonesia, Presiden Sebaiknya Ajak Daerah Kolaborasi Tangani Covid19, https://mediaindonesia.com/read/detail/304146-presidensebaiknya-ajak-daerah-kolaborasi-tangani-covid-19, akses pada 22 mei 2020

Nasional Kompas, Kebijakan PSBB Belum Tegas Tak Efektif Atasi COVID19,https://nasional.kompas.com/read/2020/04/04/15202701/p engamat-kebijakan-psbb-belum-tegas-tak-efektif-atasi-covid, akses pada 22 mei 2020

Peraturan Gubernur Daerah Khusus Ibukota Jakarta Nomor 47 Tahun 2020 Tentang Pembatasan Kegiatan Berpergian Keluar Dan/Atau Masuk Provinsi Daerah Khusus Ibukota Jakarta Dalam Upaya Pencegahan Penyebaran Corona Virus Disease 2019 (Covid-19) 
Administrative Law \& Governance Journal. Volume 3 Issue 2, June 2020| ISSN. 2621-2781 Online

R. Tumengko, Alent. Kebijakan Pemerintah dan Pertanggungjawabannya Dalam Rangka Good Governance

Telly Sumbu, Kamus Umum Politik dan Hukum, Jala Permata Askara, Jakarta 2010, hal 569

Undang-Undang No. 32 Tahun 2004 Tentang Pemerintahan Daerah

Undang-Undang No. 6 Tahun 2018 Tentang Kekarantinaan Kesehatan 